\title{
OBITUARY
}

\section{LEV ALEKSANDROVICH MOLOKOV}

Russian hydraulic engineering has suffered a great loss. Lev Aleksandrovich Molokov, prominent specialist and scientist in the field of engineering geology and doctor of geological and mineralogical sciences, has died.

After graduating from Moscow State University, L. A. Molokov devoted his knowledge and experience to engineering-geological substantiation of hydraulic structures. Having begun with surveys on hydraulic-engineering objects in Central Asia, while still a young engineer he headed geological works on one of the largest objects at that time - the Kakhovka hydroelectric station.

Surveys on the largest objects are associated with his name: Bratsk, Ust'-Ilim, Toktogul, Nurek, and other hydrostations, as well as foreign ones, particularly the Hoa Binh hydrostation in Vietnam, where for a long time he performed the duties as chief geologist.

Lev Aleksandrovich Molokov gave advice on the construction of foreign objects in Poland, Burma, and other countries. His work everywhere was distinguished by high professional skill and display of professional qualities.

L. A. Molokov devoted great attention to generalization of the experience of engineering-geological surveys for hydraulic structures, starting in 1968 as deputy chief of the technical department of engineering surveys of the All-Union Planning, Surveying, and Scientific-Research Institute (Gidroproekt). He wrote about 100 works, including eight monographs. He devoted much attention to the problem of the interaction of hydraulic structures and the geological environment, to which his doctoral dissertation, successfully defended in 1985 , was devoted.

Lev Aleksandrovich was a member of the editorial board of the journal Gidrotekhnicheskoe Stroitel'stvo, providing a high quality of articles on engineering-geology topics. He headed methodological works at Gidroproekt. The Departmental Building Codes "Engineering-Geological Surveys for Hydrotechnical Construction" were published under his supervision, as was work on drawing up recommendations on engineering-geological documentation and observation of construction excavations at constructed and operating structures, surveys for small hydrostations, and other guidelines.

L. A. Molokov devoted much attention to training engineering geologists. In 1968-1976 he worked as a docent at the Moscow Geological Exploration Institute, and recently was chairman of the State Examination Board of the institute, and directed the training of graduate students.

L. A. Molokov enjoyed indisputable authority among engineering geologists, participating in numerous expert evaluations and the solution of the most complex problems of hydrotechnical construction.

For his services in the field of engineering geology, Lev Aleksandrovich was conferred the title "Honored Geologist of the RSFSR," was awarded medals and orders of Poland and Vietnam.

Comrades working with him could always count on highly skilled and friendly help in all interesting problems.

The bright memory of Lev Aleksandrovich Molokov will always be kept in our hearts.

Translated from Gidrotekhnicheskoe Stroitel'stvo, No. 2, p. 51, February, 1993. 